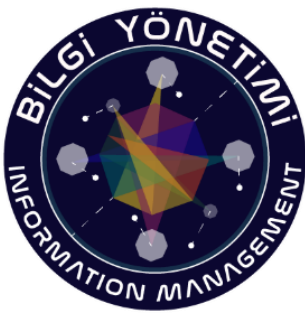

\section{Bilgi Yönetimi Dergisi}

Cilt: 4 Sayı: 1 Yıl: 2021 https://dergipark.org.tr/tr/pub/by

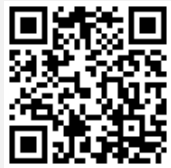

Hakemli Makaleler

Araştırma Makalesi

\section{Makale Bilgisi}

Gönderildiği tarih: 14.08. 2020

Kabul tarihi: $\quad$ 28.09. 2020

Yayınlanma tarihi: 30.06 .2021

Article Info

Date submitted:

14.08. 2020

Date accepted:

28.09. 2020

Date published:

30.06. 2021

Anahtar sözcükler

Bilgi Toplumu, Bilgi Politikast, Kütüphaneler, Azerbaycan

Keywords

Information Society, Information Policy, Libraries, Azerbaijan

DOI numarasi

10.33721/by.780476

ORCID

0000-0002-3797-0815 (1)

0000-0003-4040-3966 (2)

\title{
Azerbaycan'ın Ulusal Bilgi Toplumu Politikasında Kütüphane Kurumuna Yaklaşım ve Bir Model Önerisi
}

\author{
Approach to the Library Organization in Azerbaijan's \\ National Information Society Policy and a Model Proposal
}

\section{Eda Peri ERBAŞ}

Hacettepe Üniversitesi Bilgi ve Belge Yönetimi Bölümü Doktora Öğrencisi, edaperierbas@gmail.com

\section{Bülent YILMAZ}

Hacettepe Üniversitesi Bilgi ve Belge Yönetimi Bölümü Öğretim Üyesi, byilmaz963@gmail.com

$\ddot{O} \mathbf{z}$

Bu çalışmanın temel amacı, Azerbaycan Cumhuriyeti'nin ulusal bilgi toplumu politikasında kütüphane kurumuna yönelik yaklaşımı değerlendirmektir. Bu bağlamda, Azerbaycan'ın ulusal bilgi toplumu politikası ile ilgili politika belgeleri incelenmiştir. Elde edilen bulgulara göre, Azerbaycan Cumhuriyeti'nde bilgi toplumu oluşturma konusunda önemli adımlar atılmasına karşın ulusal bilgi toplumu politikası geliştirmede kütüphanelerin işlevleri "sınırlı biçimde" dikkate alınmıştır. İlgili politika belgelerinin bazılarında kütüphane kurumu dolaylı olarak ve geleneksel işlevleri ile zayıf bir biçimde, bazı belgelerde ise doğrudan ve güçlü bir biçimde değerlendirilmiştir. Çalışmanın sonunda, Azerbaycan'da kütüphane kurumu ile ilişkisi bağlamında bir ulusal bilgi toplumu politikası geliştirmeye katkı sağlayacak önerilerde bulunulmuş ve ulusal bilgi politikasıkütüphane kurumu ilişsisi üzerine geliştirilen bir model önerisi sunulmuştur.

\section{Abstract}

The main purpose of this study is to evaluate the approach towards the library institution in the national information society policy of the Republic of Azerbaijan. In this context, policy documents on Azerbaijan's national information society policy have been examined. According to the findings obtained, although important steps have been taken to create an information society in the Republic of Azerbaijan, the functions of libraries have been considered in a "limited way" in developing a national information society policy. In some of the relevant policy documents the library institution has been evaluated indirectly and weakly with its traditional functions, in some documents directly and strongly. At the end of the study, suggestions were made to contribute to the development of a national information society policy in terms of its relationship with the library institution in Azerbaijan and a model proposal developed on the relationship between the national information policy and the library institution was presented.

\section{Giriş}

1990'lı yıllardan itibaren literatürde yoğunlukla görülmeye başlanan bilgi toplumu kavramı, günümüzde bilgi ve iletişim teknolojileri sayesinde hızla ve çok miktarda üretilen, kolaylıkla erişilen ve işlenip depolanarak gelecek nesillere aktarılan bilgiyi önemseyen, ona ekonomik ve sosyal değer yükleyen toplumlar için kullanılmaktadır. Yazının tarihte bulunuşundan başlayarak günümüze kadar yazılı, basıl1, 
elektronik vb. ortamlarda bulunan doğru ve güvenilir bilgilerin toplanarak korunduğu, saklandığ1 ve yararlanmaya sunulduğu kütüphaneler, bilgi toplumunun oluşmasında bilgi merkezleri olarak çok önemli işlevler görür. Bu nedenle, bilgi toplumunun oluşturulmasına yönelik politika ya da stratejilerin geliştirilmesinde kütüphanelerin organik yapı unsuru olarak dikkate alınması gerekmektedir.

Aliguliyev ve Mahmudov (2016)'a göre bilgi toplumu, insan faaliyetlerinin tüm alanlarındaki karmaşık değişikliklerinin ürünüdür. Bilgi toplumunun bilimsel sorunları teknoloji, ekonomi, hukuk, siyaset bilimi, felsefe, sosyoloji, psikoloji, pedagoji, kültür, dilbilim vb. alanlara göre koordineli araştırma yapılmasını gerektirir (Aliguliyev ve Mahmudov, 2016, s.3).

Azerbaycan Cumhuriyeti son yıllarda bilgi toplumunun oluşumu için sosyo-ekonomik, siyasi ve yasal altyapının geliştirilmesi kapsamında stratejik önem gösteren resmi programlar yayımlamış ve kanunlar çıkarmıştır. Bu çabaların temel amacı, Azerbaycan'ın uluslararası ilişkilerini siyasi, hukuki, ekonomik, sosyal ve diğer alanlarda genişletmek, küreselleşen dünyada güvenilir bir ortak olarak konumunu güçlendirmek, ulusal bir elektronik bilgi alanı yaratmak ve sürdürülebilir kalkınmayı sağlamaktır (Gasımova ve Elekberova, 2006). Azerbaycan Cumhuriyeti'nde yenilikçi, bilime ve bilgiye dayalı ekonomi oluşturarak, nitelikli personel ve modern insan sermayesine odaklanan bilgi toplumu politikasının gelişimine olumlu katkı sağlayarak ilerde geniş bilgiye sahip bir toplumun gelişimini hizlandıracaktır (Ahmedov, 2013).

Bu çalışmada, öncelikle bilgi politikası, bilgi toplumu ve bilgi toplumu-kütüphane ilişkisi teorik çerçevede ele alınmış ve daha sonra Azerbaycan'ın ulusal bilgi toplumu politikası kütüphaneler bağlamında değerlendirilmiştir. Çalışma sonunda, kütüphaneleri ulusal bilgi toplumu politikası içine alan bir model önerilmiştir.

\section{Bilgi Politikası, Bilgi Toplumu ve Kütüphaneler}

Her ülke dünyadaki toplumsal gelişim ve yenilikleri takip ederek kendi toplumlarının kalkınması için belli başlı hedefler koyar. Bu hedeflere ulaşmak için strateji/politikalar geliştirir. Strateji kavramının kuramsal olarak politika kavramı (genel siyaset anlamı dışındaki özel anlamı) ile genelde aynı içeriğe sahip olduğu söylenebilir. Strateji ya da politika, herhangi bir toplumsal alanda önceden belirlenen hedeflere ulaşmak için izlenecek yol ve yöntemler ile bu çerçevede oluşturulan yasa, yönetmelik, kararname, rapor vb. yasal belgeler ve geliştirilen planlar, programlar ve projeler bütünü olarak tanımlanmaktadır (Yılmaz, 2010, s.264, 265). Bu bağlamda bilgi politikast, bilgi kaynakları, bilgi hizmetleri, bilgi sistemleri ve bilgi altyapısı unsurları çerçevesinde geliştirilen hedefler ve bu hedeflere ulaşmak için izlenecek yol ve yöntemleri içeren stratejiler anlamına gelir. Kurumsal, bölgesel ve uluslararası düzeylerde geliştirilebilen bilgi politikalarının ulusal düzeyde olanına ise ulusal bilgi politikası denir (Yılmaz, 1997, s.22). Kısaca, bilgi politikası, bilgi kaynakları, hizmetleri, sistemleri ve altyapısının oluşturulması ve geliştirilmesine rehberlik eden strateji, plan ve programlardır (Montviloff, 1990, s.7).

Toplumsal gelişimin önemli kaynaklardan biri olan bilgi, teknolojinin gelişimi ve yaygın kullanımı ile birlikte hızla artmaktadır. Bilgi üretiminin artması, bu bilgilerin güvenilir olup olmadığ tartışmalarını beraberinde getirmektedir. Bu durumda bilgi toplumu ve bilgi politikası kavramlarının doğru bir şekilde benimsenmesi gerekmektedir. Bilgi toplumu son birkaç on yılda yalnız bilgi dünyasında değil hemen tüm alanlarda en sik duyulan kavramlardan birisi olmuştur.

Günümüzde 'sanayi ötesi toplum', 'postmodernizm', 'sibernetik kapitalizm', 'kontrol devrimi' gibi terimler çoğu zaman 'bilgi toplumu' terimi ile eş anlamlı olarak kullanılmaktadır. Öte yandan 'bilgi toplumu' terimini herkes farklı tanımlamaktadır. Bazen bilginin işlenmesinde, depolanmasında ve dağıtımında son yüzyılda meydana gelen teknolojik gelişmeler ön plana çıkarılarak bilgisayar ve iletişim teknolojisi (bilgi teknolojisi) ağıllıklı bir bilgi toplumu tanımı yapılmakta, bazen de bir ülkedeki Gayri Safi Milli Hasılanın (GSMH) kaçta kaçının bilgi sektöründen geldiğine ya da bilgi ile ilgili işlerde çalışan insan gücünün toplam işgücüne oranına bakılarak ekonomik ya da mesleki ağırlıklı tanımlar yapılmaktadır(Tonta, 1999, s.364). 
Tonta ve Küçük (2005)'e göre bilgi, ekonomik bir meta niteliği kazanarak entelektüel ve teknolojik kapasitesi yüksek toplum olarak tanımlamaktadır. Böylece bireysel ve toplumsal sorunların çözümünde bilgiyi temel alan, bilgi üretiminin ve kullanımının geçmişe göre çok daha yoğun olduğunu ifade etmektedir. Bilgi toplumunu sanayi toplumundan ayıran temel unsur ve özellikler olarak bilgisayar, zihinsel emek, bilgi üretme gücü, bilimsel bilgi, bilgi kullanım alanlarının genişlemesi, entelektüel endüstriler, fonksiyonel toplum, katılımcı demokrasi, sivil hareketler ve küreselleşme gibi kavramlara dikkat çekmektedirler (Tonta ve Küçük, 2005, s.4,5).

Bilgi toplumunun başlıca gereklilikleri ise şöyle sıralanabilir:

- Toplumun bilgi ihtiyaçlarını karşılamak,

- Bilgi ortamlarının oluşumunu ve gelişimini sağlamak,

- Yüksek bilgi kültürü oluşturmak için bireylerin bilgi ağlarına erişimini sağlamak,

- Bireylerin bilgi güvenliğini sağlamak (Süleymanov ve diğ., 2015, s.95,96).

Kısaca, bilgi toplumu gereklilikleri bilgi kaynakları, bilgi hizmetleri, bilgi sistemleri ve bilgi altyapısı unsurları olarak ele alınmaktadır.

Bilgi toplumunun oluşturulmasında karşılaşılan sorunlar genelde şu başlıklar altında özetlenmektedir:

- Bilgi toplumu altyapısının yeterince oluşturulmaması,

- "Akıllı" teknolojilerin geliştirilmesinin yaygınlaştırılamaması,

- Güvenilir veri analizi ve kimlik tanımlama yöntemlerinin yetersiz olması,

- Vatandaşların bilgi haklarının yeteri düzeyde sağlanamaması,

- İnternete yönelik yasal düzenlemeler ve siber suçlarla mücadelede sorunlar,

- Fikri mülkiyet ve tüketici haklarının korunması problemleri,

- Bilgi toplumu kavramları/modellerini belirleyerek bilgi politikası oluşturmada yetersizlikler,

- Bilgi kültürü, kültürel ve dilsel çeşitliliğin korunmasındaki sorunlar (Aliguliyev ve Mahmudov, 2016, s.14,15).

Geçmişten bu yana sürekli olarak değişen ve gelişen teknoloji günümüzde, yaşadığımız döneme "bilgi çağı/toplumu" adını verdirecek denli hız ve nitelik değiştirmiştir. Bir başka deyişle, tümüyle bilgi ve iletişim teknolojilerine dayalı bir değişim sonucunda, bilgi, geçmişle kıyaslanamayacak kadar çok ve hızlı biçimde artmaktadır. Teknolojide ve ona dayalı olarak bilginin artışında görülen bu değişim doğal olarak ekonomik, sosyal, kültürel ve siyasal gelişmelere de yansımakta, genel bir toplumsal değişim sürecini tetiklemiştir. Tetiklenen bu toplumsal değişim süreci "Bilgi Toplumu" adı verilen yeni bir toplumsal yapıyı ortaya çıkarmıştır. Tüm toplumsal alanların bilgiye dayalı olduğu bu yeni toplum yapısı yeni stratejik yaklaşımları ve politikalara gereksinim duymaktadır. Çünkü yeni bir toplum eski politikalarla sürdürülemez. Bu nedenle, bilgi toplumunun oluşturulmasında eski stratejilerin gözden geçirilerek yeni stratejilerin geliştirilmesi zorunlu hale gelmiştir. Geliştirilecek ve adına "Bilgi Toplumu Politikası" diyebileceğimiz bu yeni strateji ya da politikalarda bilgi üzerine temellenen bir kurumun ve alanın güçlü biçimde yer alması ise zorunlu bir koşul olarak kabul edilmelidir. Açıkça söylemek gerekirse, kütüphane kurumu Bilgi Toplumu politikasının organik (olmazsa olmaz) bir parçası olarak kabul edilmek durumundadir.

Her türlü bilginin bulunduğu ve sunulduğu kurumlar olarak kütüphaneler, ekonomik eşitsizliği ortadan kaldırarak tüm bireylere doğru ve güvenilir bilgiye ücretsiz erişimi sağlamaktadır. Böylece teknolojiye erişebilen veya erişemeyen insanlar arasındaki dijital uçurumu (bölünme) ortadan kaldırarak herkesin eşit bir şekilde bilgiye erişimini kolaylaştırmaktadır. Bu bağlamda, bilgi toplumu-kütüphane ilişkisi kısaca şu şekilde vurgulanabilir:

- Kütüphaneler, bilgi toplumunun temel ve güvenilir kaynaklarıdır.

- Kütüphaneler, bulundurdukları bilgi kaynaklarını içerik açısından doğru bir şekilde değerlendiren uzmanlaşmış kurumlardır.

- Kütüphaneler, web tabanlı çeşitli materyaller sunan kurumlardır.

- Kütüphaneler her türlü basılı ve elektronik bilgi ve belgelerin depolanması ve arşivlenmesi işlemini gerçekleştiren kurumlardır (Yılmaz, 2010, s.269). 
Kısaca, ortaya çıktığı çağlardan bu yana insanlığın her türlü bilgi ihtiyacını karşılayan temel kurumlar olarak kütüphaneler bu işlevlerini farklı araçlar ile bilgi teknolojilerine dayalı olarak günümüzde de güçlü biçimde sürdürmektedir. Bu nedenle, kütüphaneler bilgi kavramına dayalı bir olgu olan bilgi toplumunun organik bileşeni olarak kabul edilmek durumundadır. Bir başka deyişle, bir toplumun bilgi toplumu kimliği kazanmasında kütüphanelerin doğru değerlendirmesi ve onların toplumsal hayat içinde doğru konumlandırması doğrudan etkilidir ve önemli bir kolaylaştırıcıdır.

\section{Araștırmanın Amaç, Kapsam ve Yöntemi}

Bu çalışmanın amacı, Azerbaycan'da bilgi toplumu oluşturmaya yönelik olarak geliştirilen politika ve strateji belgelerinde kütüphane kurumuna ilişkin yaklaşımın özelliklerini ortaya koymaktır. Bir başka deyişle, çalışmada Azerbaycan'ın bilgi toplumu politikasının kütüphane kurumu bağlamında analiz edilmesi hedeflenmiştir. Dolayısıyla konu, bu politikada kütüphane kurumuna yaklaşım ile sınırlandırılmıştır. Bu kapsamda, Azerbaycan'da bilgi toplumuna yönelik olarak çıkarılan ve halen yürürlükte olan yasalar, kararnameler, kanunlar, genelgeler ve ulusal programları incelenmiştir. Bu tür belgeler bir ülkede belirli bir alana ilişkin ulusal politika yaklaşımını ortaya koymada incelenmesi gereken ulusal politika belgeleri olarak kabul edilir (Yılmaz, 1997, s.24). Bu çalışma kapsamında incelenen belgeler şunlardır:

\section{Anayasa}

- A.C. Anayasas1-1995.

\section{Kanun}

- Enformasyon, Bilgilendirme ve Bilgi Güvenliği hakkında 460 Sayılı A. C. Kanunu.

\section{Ulusal Strateji Belgesi}

- A.C. 2014-2020 Bilgi Toplumunun Geliştirilmesine Yönelik Ulusal Strateji.

\section{Kararname}

- Azerbaycan 2020: Geleceğe Bakış Kalkınma Konsepti (29.12.2012 tarihli Kararname).

\section{Genelgeler}

- Azerbaycan'da Kütüphanelerin Faaliyetlerinin Geliştirilmesi Hakkında 20 Nisan 2007 tarihli Genelge.

- Azerbaycan Dilinde Latin alfabesi ile Kitle Yayınların Gerçekleştirilmesine Yönelik A.C. Cumhurbaşkanının 12 Ocak 2004 tarihli Genelgesi.

- A.C. 2010-2012 İletişim ve Bilgi Teknolojileri Geliştirme Devlet Programının (Elektron Azerbaycan) onaylanması hakkında 1056 sayılı Genelge.

\section{Programlar}

- A.C. 2008-2013 Yıllarında Kütüphane ve Bilgi Alanının Geliştirilmesine Yönelik Devlet Programı.

- Okullara Bilgi ve İletişim Teknolojileri Sağlama Programı (2005-2007).

Bu araştırmanın problemi, "Azerbaycan'da bilgi toplumu politikasının geliştirilmesinde kütüphane kurumuna ilişkin yaklaşımın özellikleri nasıldır?" şeklinde ifade edilebilir. Bu bağlamda araştırmanın hipotezi, "Azerbaycan'da bilgi toplumu politikası belgelerinde kütüphane kurumu belirli bir sinırlılıkta ve nitelikte (bazen güçlü bazen zayıf, bazen doğrudan ilişkili ve bazen dolaylı olarak ilişkili biçimde) değerlendirilmektedir" biçiminde oluşturulmuştur. Betimleme yöntemi ile gerçekleştirilen araştırmada, veriler içerik analizi yöntemi ile değerlendirilmiştir.

\section{Azerbaycan'ın Bilgi Toplumu Politikası ve Kütüphaneler: Bulgular ve Değerlendirme}

Güney Kafkasya ve Orta Asya'nın en eski tarih ve kültürüne sahip olan Azerbaycan Cumhuriyeti, doğudan Hazar Denizi, kuzeyden Rusya, kuzeybatıda Gürcistan ve güneyinde İran ile komşudur. Azerbaycan ve Türkiye'nin 15 kilometre uzunlukta olan sınırları Aras nehri ve Sederek (Nahçıvan) boyunca uzanmaktadır (Abbasov, 2005, s.3). Azerbaycan, zengin kültürel mirasa sahip üniter bir 
anayasal cumhuriyettir. 28 Mayıs 1918'de Doğu'daki ilk demokratik parlamenter cumhuriyet olan Azerbaycan Demokratik Cumhuriyeti ilan edilmiştir. 1920'de Azerbaycan Sovyetler Birliği'ne katılmış, 1991'de tekrar bağımsızlığını kazanmıştır (Nuriyeva, 2015, s.254,299). Ülkenin nüfusu 5 Mayıs 2020 itibariyle 10.067.000'dir (ACDİK, 2020).

Bu bölümde, Azerbaycan'ın ulusal bilgi toplumu politikasına yönelik verileri elde etmek amacıyla daha önce araştırmanın amacı, kapsamı ve yöntemi kısmında belirtilen ilgili ulusal politika belgeleri anayasa, kanunlar, ulusal strateji belgesi, kararnameler, genelgeler ve programlar incelenmektedir.

\subsection{Anayasa}

\section{Azerbaycan Cumhuriyeti Anayasast-1995}

Azerbaycan'ın en temel hukuki belgesi olan A. C. Anayasası'na (1995, madde: 42, 51) göre edebi, sanatsal, bilimsel, teknik ve diğer yaratıcılık türlerinin özgürce yayılmasını gerçekleştiren devlet, her bir vatandaşına ücretsiz eğitim hakkı tanımaktadır. Bu ifadenin, Azerbaycan'da bilgi toplumunun oluşturulmasına önemli bir yasal dayanak sağladığı söylenebilir. Sözü edilen ifadede geçen "devletin edebi, sanatsal, bilimsel, teknik ve diğer yaratıcılık türlerinin yayılmasını gerçekleştirmek görevi" günümüz bilgi ve iletişim teknolojileri düşünüldügünde kütüphane kurumunu zorunlu olarak bilgi toplumu politikasının bir parçası yapma durumunu gündeme getirir. Çünkü kütüphaneler bilgi toplumunda yaratıc1lık türlerinin yayılmasında yani bilgiye erişimde başlıca kurumlar olarak işlev görür. Dolayısıyla bu madde dolaylı olarak kütüphanelerin bilgi toplumun zorunlu kurumları olduğuna işaret etmektedir. Anayasalar çok genel çerçeveli politika belgeleri olduğu için her konu için doğrudan ve ayrıntılı ifade beklentisi gerçekçi değildir.

\subsection{Kanun}

\section{Enformasyon, Bilgilendirme ve Bilgi Güvenliği Hakkında 460 sayılı A. C. Kanunu}

Söz konusu kanun, bilgi kaynaklarının üretimini, işlenmesini, depolanmasını, bilginin yayılmasını, bilgi sistemlerini ve teknolojilerini, destek araçlarının oluşturulmasını ve kullanımını, bilgi güvenliğine ilişkin hususları ve bilgi süreçlerine katılımı içermektedir. Bu kanun kütüphane kurumu ve bilgi toplumuna yönelik olarak şunları ortaya koymaktadır:

- Bilgi kaynakları: Bilgi sistemlerindeki (kütüphaneler, arşivler, fonlar, veri bankaları, vb.) belgeler (460 say1l Kanun, 1998, s.1).

Bilgi güvenliğinin sağlanmasında önemli yere sahip bu kanunda bilgi kaynakları çerçevesinde " kütüphaneler, arşivler, fonlar, veri bankaları" belirtilmiştir.

Yukarıda incelenen enformasyon, bilgilendirme ve bilgi güvenliği kavramları ile ilişkili olması nedeniyle Azerbaycan Cumhuriyeti'nde bilgi toplumunun oluşturulması yönündeki önemli gelişmelerden birisi olan e-devlet projesinden de söz etmek yararlı olacaktır. Proje çerçevesinde, devlet kurumlarının veri tabanlarının ve bilgi sistemlerinin uyumu, vatandaş dilekçelerinin devlet kurumlarına ulaştırılması, e-hizmetlerin tek elden düzenlenmesi ve kullanılması için e-devlet portalı kurulmuştur.

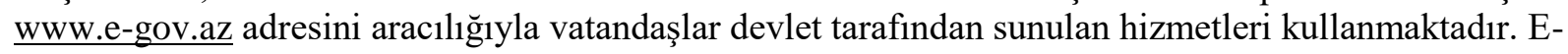
devletin gelişmesini sağlamak için e-imza altyapısı oluşturulmuş ve mobil kimlik doğrulama sertifika merkezi kurulmuştur. Tüm bu temel uygulamalar sayesinde ilgili alanlarda 2020 hedeflerini en üst düzeyde gerçekleştirmek mümkün olacaktır (Hacızade, 2015, s.79). Küresel ölçekte gittikçe hızlı bir şekilde gelişen bilgi teknolojileri sayesinde toplumlar yeni ürün ve hizmetlerin sunumu için e-devlet gibi uygulamalardan yaralanmaktadır. Özellikle resmi kurumlarda e-devlet uygulamalarının yürütülmesinde hem teknik altyapı hem de gerçekleştirme açısından genellikle kütüphaneciye (bilgi yöneticisine) gereksinim duyulmaktadır. Bu durum Azerbaycan için de geçerlidir. Dolayısıyla bir bilgi toplumu gelişmesi sayılan e-devlet uygulaması Azerbaycan'da kütüphaneleri biraz daha öne çıkarmaya başlamıştır. Bir başka deyişle, e-devlet uygulamaları kütüphanelerin ve kütüphanecilerin bilgi toplumunun önemli bileşenleri olarak kabul edilmesinde rolü olacaktır. Çünkü vatandaşların e-devlet uygulamalarını kullanabilmeleri için hem gerekli dijital bilgi ve becerileri edinmeleri hem de teknolojik olanaklara sahip olmaları açısından kütüphaneler önemli işlevlere sahiptir. 


\subsection{Ulusal Strateji Belgesi}

\section{A.C. 2014-2020 Bilgi Toplumunun Gelişstirilmesine Yönelik Ulusal Strateji}

Azerbaycan Cumhuriyeti Ulusal Stratejisi, bilgi toplumunun temellerinin oluşturulması, bilişim ve iletişim teknolojilerinin vatandaşlar, toplum, özel sektör ve devlet kurumları tarafından yaygın olarak kullanılması amacıyla hazırlanmıştır. Bu strateji ile modern yeniliklerin tek bir noktadan uygulanması yoluyla vatandaşlara daha iyi hizmet sunmak için devlet kurumlarının veri tabanlarının karşılıklı entegrasyonu, e-hizmetlerin organize edilmesi sürecinin hızlandırılması, bu alandaki yönetim sisteminin iyileştirilmesi amaçlanmıştır. Azerbaycan Cumhuriyeti Cumhurbaşkanı'nın 13 Temmuz 2012 tarihli ve 685 sayılı Kararnamesi ile Azerbaycan Cumhuriyeti Cumhurbaşkanı Vatandaş Hizmetleri ve Sosyal Yenilikler Devlet Ajansı ve kısa bir süre içinde olumlu bir deneyim olduğunu kanıtlayan "ASAN" Hizmet" merkezleri kurulmuştur. Devlet kurumlarının bilgi kaynaklarını ve sistemlerini olası tehditlerden korumak, siber güvenlik konusunda ulusal eğitim ve farkındalığı artırmak için, Azerbaycan Özel Devlet Koruma Servisi Özel İletişim ve Bilgi Güvenliği Devlet Ajansı Elektronik Güvenlik Merkezi, A.C. İletişim ve Yüksek Teknolojiler Bakanlığı'na bağlı olarak faaliyet göstermektedir. Bu kapsamda Ulusal Stratejinin temel amaçları şunlardır:

- Bilgi toplumunun kurulması, vatandaşların, toplumun ve devletin gelişmesi için fırsatların etkin kullanımı, ülkenin sürdürülebilir kalkınmasını geliştirmek,

- Eğitim, sağlık, sosyal koruma ve diğer sosyal alanlarda topluma sunulan hizmetlerin kalitesini artırmak,

- Bilgi toplumu bağlamında etkili düzenlemelerin uygulanması, özellikle her bireyin bilgiye erişme ve iletişim kurma hakkının sağlanması,

- Bilgi ve telekomünikasyon teknolojileri alanında üst düzey bilimsel ve nitelikli personelin eğitimi.

Bu alandaki ana faaliyetler olarak şunlar belirlenmiştir:

- Azerbaycan tarihi, edebi ve kültürel miras üzerine internet kaynaklarının (dijital arşivler) oluşturulması ve geliştirilmesi;

- Genel gelişim, eğitim, sağlık ve diğer alanlarda dijital bilgi erişim sistemlerinin oluşturulması;

- Kütüphanelerde, arşivlerde ve müzelerde BİT (bilgi ve iletişim teknolojileri) uygulamalarının genişletilmesi, elektronik kütüphane ağı kurulması.

Ulusal Stratejinin uygulanmasını değerlendirmek için sivil toplum kuruluşlarının katılımıyla uluslararası yöntemlere dayanan izleme ve kamuoyu yoklamaları yapılmaktadır. Ulusal Stratejinin uygulanması için yapılan çalışmalar hakkında kamuoyuna düzenli olarak bilgi verilmektedir. Ulusal Stratejinin uygulanması ile beklenen sonuçlar ise şöyle sıralanmıştır:

- Bilgi toplumunun yarattığı tüm firsatlardan yararlanmak için toplumun kapsamlı gelişimi için elverişli koşullar yaratılacaktır;

- İnternet özgürlüğü ve bilgiye erişim gibi evrensel değerler sağlanacak ve modern teknolojiler vatandaşların hak ve özgürlüklerinin gerçekleştirilmesine yardımcı olacaktır;

- Uzaktan eğitim, e-ticaret ve diğer modern hizmetlerin geniş uygulaması sağlanacaktır;

- Modern BİT'in devlet kurumlarında, yerel yürütme otoritelerinde ve belediyelerde uygulanması yaygınlaştırlacak, etkin, şeffaf ve kontrol edilebilir bir kamu idaresi kurulacak ve genel nüfusun yönetim sürecine katılımı sağlanacak, e-hizmetlerin kalitesi artırılacaktır;

- Ülkenin bilgi güvenliği etkin bir şekilde korunacak, bu alanda bilinçlendirme artırılacak ve bilgi güvenliği kültürü güçlendirilecektir;

- Azerbaycan dilinin ulusal elektronik bilgi alanında kullanımı, BİT'in kültürel mirasın korunmasında kullanımı yaygınlaştırılacaktır (2014-2020 Ulusal Strateji, s.2,7,8,12,14,16).

Azerbaycan'da bilgi toplumunun geliştirilmesine yönelik olarak çıkarılan "Ulusal Strateji" kapsamında birçok farklı alanda gelişim ve kalkınmayı gerçekleştirebilmek için adımlar atılmaktadır. Liderlik, eşitlik, şeffaflık, işbirliği, farkındalık ve yenilik gibi kavramların esas alındığı bu stratejide Azerbaycan Cumhuriyeti'nin tarihsel, edebi ve kültürel mirasına yönelik kaynakların aynı zamanda internet

\footnotetext{
"ASAN: "Azerbaijan Service and Assessment Network" (Azerbaycan Hizmet ve Değerlendirme A $\breve{g}$ )
} 
kaynaklarının (dijital arşivler) oluşturulması ve geliştirilmesi, kütüphane, arşiv ve müzelerde teknoloji uygulamalarının genişletilmesi, elektronik kütüphane ağının oluşturulması, kültürel mirasın korunması ve dijitalleştirme sürecinin hızlandırılması gibi önemli konuları kapsamaktadır. Dolayısıyla bu önemli bilgi toplumu belgesinde kütüphane, arşiv ve müzeler gibi bilgi merkezleri doğrudan ve dolaylı olarak adları ve işlevleriyle yer almıştır. Ayrıca kültürel miras, dijital arşivler, elektronik kütüphane ağının oluşturulması ve dijitalleştirme gibi kavramların doğrudan kütüphane, arşiv ve müzeler ile ilişkilendirilmesi bilgi toplumu politikasında bu kurumlara yönelik yaklaşımın niteliğini yükseltmektedir.

Bu politika belgesinin Azerbaycan'ın bilgi toplumu yaklaşımı ile doğrudan ilgili temel belge olduğunu söylemek yanlış olmayacaktır. Bu nedenle bu belgede kütüphane kurumuna ilişkin yaklaşımlar büyük önem taşımaktadır. Söz konusu bu belgede "kütüphane, arşiv ve müzeler bilgi toplumu politikasının hayata geçirilmesinde olmazsa olmaz kurumlardır" gibi doğrudan ve güçlü bir yaklaşım yer almasa da dolaylı ilişkilendirmelerde bulunulmuştur. Bu özellik, araştırmamızın hipotezinde geçen "belirli sınırlılıkta ve nitelikte" ifadesinin kanıtı olarak da değerlendirilebilir.

\section{4. Kararname}

\section{Azerbaycan 2020: Geleceğe Bakış Kalkınma Konsepti (29.12. 2012 Tarihli Kararname)}

Bu kararname kapsamında e-öğrenme teknolojilerinin uygulanması daha da genişletilerek öğretmenler ve öğrenciler için sanal bir öğrenme ortamı oluşturulması hedeflenmiştir. Bu amaçla, tüm konularda eöğrenme ve metodolojik kaynakların geliştirilmesine devam edilecek, e-kaynakların güvenli bir şekilde depolanması ve bunlara kolay erişimin sağlanması için "bulut" teknolojileri kullanılacaktır. Yine bu kararname çerçevesinde, ücretsiz eğitim kaynakları oluşturulacak, telif hakkı lisansları sağlanacak, eğitim sürecine entegre edilecek ve kamuya açık hale getirilecektir. Yaşam boyu öğrenmeye yönelik artan talebi karşılamak için kütüphane faaliyetleri modernize edilecek, elektronik kütüphane sayıs1 artırılacak, uzaktan eğitimin geliştirilmesi desteklenecek ve uzaktan eğitim yükseköğretim kurumlarında yaygın olarak kullanılacaktır (Kararname, 2012: Azerbaycan 2020, s.27).

Azerbaycan 2020: Geleceğe Bakış Kalkınma Konsepti, kütüphane kurumuna yaklaşım bağlamında özellikle eğitimle olan ilişkisi çerçevesinde değerlendirilirse, yaşam boyu öğrenmeye ve özellikle uzaktan eğitime yönelik olarak artan talepleri karşılamak amacıyla kütüphanelerin yenilenmesine, ekütüphanelerin sayısının artırlmasına, uzaktan eğitimin geliştirilmesine ve özellikle yükseköğretim kurumlarında bu eğitimin desteklenmesi konusuna doğrudan atıfta bulunulmuştur. Bilgi toplumu politikası açısından kütüphanelere yönelik bu güçlü ilişkilendirmeler olumlu bir yaklaşım olarak değerlendirilmelidir. Kütüphanelerin bilgi toplumunun temel gelişmelerinden olan yaşam boyu öğrenme ve uzaktan eğitim gibi kavramların parçası olarak görülmesi ve doğrudan kütüphanelerin bu nedenlerle de geliştirileceği vurgusu önemlidir.

\subsection{Genelgeler}

\section{Azerbaycan'da Kütüphanelerin Faaliyetlerinin Geliştirilmesi Hakkında 20 Nisan 2007 tarihli Genelge}

$\mathrm{Bu}$ politika belgesinde tarihsel, kültürel, edebi, bilimsel ve felsefi mirasın korunmasında, gelecek nesillere aktarılmasında ve toplumun entelektüel potansiyelinin geliştirilmesinde önemli bir rol oynayan kütüphanelerin faaliyetlerini geliştirme hedefi dile getirilmiştir. Bu çerçevede Azerbaycan Milli Kütüphanesi, Azerbaycan Ulusal Bilimler Akademisi Merkez Bilim Kütüphanesi, Bakü Devlet Üniversitesi Bilim Kütüphanesi, Azerbaycan Diller Üniversitesi Kütüphanesi ve F. Köçerli Çocuk Kütüphanesi elektronik kataloglarının hizmete sunulduğu belirtilmiştir (A.C. Eğitim Bakanlığı, 2011, s.31-34).

Temel amacı, Azerbaycan'da bilgi toplumunun gerçekleştirilmesinde kütüphane ve bilgi altyapısının geliştirilmesi, kütüphane ve bilgi hizmetlerinin dünya standartlarına uyumlu hale getirilmesi, yaşam boyu eğitim koşullarının oluşturulması olan bu programda, kütüphanelere yönelik yaklaşım olumlu olarak değerlendirilebilir. Belgede kütüphaneler doğrudan bilgi toplumu politikası bağlamında ele alınmasa da söz edilen kavramlar (bilimsel-kültürel mirasın gelecek kuşaklara aktarılması gibi) bilgi toplumunun gerekleri arasında yer aldığından bu ifadeler bilgi toplumu politikası-kütüphaneler ilişkisi ifadeleri olarak da değerlendirilebilir. 
Azerbaycan Dilinde Latin alfabesi ile Kitle Yayınların Gerçekleştirilmesine Yönelik A.C. Cumhurbaşkanının 12 Ocak 2004 tarihli Genelgesi

Azerbaycan Cumhuriyeti 1990'lı yıllarda kazandığı bağımsızlığın ardından birçok alanda reformlar gerçekleştirmiştir. Bunlardan birisi de Azerbaycan Cumhuriyetinin tekrar Latin alfabesine geçişidir. Latin harfli Azerbaycan alfabesi toplum hayatının her alanında yerini almış, aynı zamanda Kiril alfabesi ile yayınlanmış olan Azerbaycan edebiyatının, kültürünün ve biliminin değerli örnekleri yeniden yayınlanmaya başlamıştır. Bu genelge kütüphaneler açısından şunları içermektedir:

- Azerbaycan Cumhuriyeti'nin tüm kütüphanelerine ve orta öğretim kurumlarının kütüphanelerine Latin alfabesiyle yeniden basılmış kitapların satın alınması için gerekli araçları sağlamak;

- İlgili kitapların Latin alfabesinde yeniden basılmasını sağlamak için Azerbaycan Cumhuriyeti Bakanlar Kurulu ve Cumhuriyetin finans kuruluşları ile birlikte; elektronik medya ve internet tarafından basılacak kitap metinlerinin yayılmasını sağlamak (A.C. Eğitim Bakanlığı, 2011, s.27, 28).

Azerbaycan'da alfabenin sık sık değişimi toplumun kültürel değişimini etkilemekle, bu etki doğal olarak kütüphane ve diğer bilgi merkezlerine de yansımaktadır. Alfabe değişiklikleri nedeniyle bazı eserler kaybolmakta, kalan eserlerin okunması belirli bir süre zorlaşmaktadır. Fakat bu son genelge ile Azerbaycan dilini, tarihini, kültürünü ve geleneklerini yansıtan hemen hemen tüm eserler ve okul kitapları Latin alfabesiyle yeniden yayımlanmaya başlamıştır. Genelge çerçevesinde kütüphanelere de bir işlev yüklenmiş ve Latin alfabesi ile yeni basılmış kitapların ve elektronik yayınların kütüphanelere alınması istenmiştir. Özellikle elektronik yayınların kütüphane dermelerine katılma çabası bilgi toplumu politikası çerçevesinde olumlu bir yaklaşım olarak değerlendirilebilir. Bu yaklaşım kütüphane dermelerinin elektronik yayınlar açısından güçlendirilmesine katkıda bulunacaktır.

\section{A.C. "2010-2012 İletişim ve Bilgi Teknolojileri Geliştirme Devlet Programının (Elektron Azerbaycan) Onaylanması Hakkında" 1056 Sayılı Genelge}

$\mathrm{Bu}$ genelge ile uygulanan program kapsamında yapılan çalışmalar sayesinde Azerbaycan Cumhuriyeti'nin iletişim ve bilgi teknolojisi pazarında özgür bir rekabet ortamı yaratmak, alana yatırım çekmek ve özel sektörü geliştirmek için önemli adımlar atılmışır. Bu kapsamda devlet kurumlarının web siteleri oluşturulmuş ve gov.az alanına yerleştirilmiştir. Devlet Programının amacı, Ulusal Stratejiden kaynaklanan görevleri yerine getirmek, cumhuriyetin bilgi toplumuna geçişini sağlamak, BİT'in gelişimini ve yaygın kullanımını sağlayarak bilgiye dayalı rekabetçi bir ekonomi oluşturmak ve geliştirmek, kamu yönetiminin etkinliğini arttırmaktır. Devlet Programında belirlenen hedeflere ulaşmak için aşağıdaki konular ele alınmaktadır:

- Modern bilgi ve iletişim altyapısının geliştirilmesi, bireylerin ve tüzel kişilerin devlet organlarının faaliyetleri ile devlet, kamu ve sektörel bilgi kaynaklarının bilgisine erişiminin genişletilmesi, bilgi ve iletişim hizmetlerinin genişletilmesi ve kalitesinin iyileştirilmesi;

- BİT çözümlerinin kamu yönetiminin her kademesinde uygulanması, devlet bilgi sistemleri ve kaynaklarının oluşturulması ve geliştirilmesi;

- Devlet kurumları tarafından sağlanan hizmetlerin verimliliğini, kalitesini ve kamu yönetimi mekanizmalarının verimliliğini artırmak için "e-devlet" uygulamasının gerçekleştirilmesi.

Devlet Programının uygulanması sonucunda beklenen gelişmeler şunlardır:

- BİT'in yaygın kullanımı nedeniyle ülkedeki bilgi toplumuna geçiş için koşulların oluşturulması;

- Bireylerin ve tüzel kişilerin BİT kullanımına aktif katılımı, bilgisayarların ve internetin yayılmasını artırma, ülkedeki "dijital geri kalmışlığı" azaltma;

- "E-devlet" platformlarının uygulanması, etkili, şeffaf ve kontrol edilebilir kamu yönetimi ve yerel özyönetimin kurulmas1;

- Azerbaycan dilinin ulusal elektronik bilgi alanında geniş biçimde uygulanması, maddi ve kültürel mirasın korunması ve geliştirilmesi için BITT kullanımını sağlamak (1056 sayılı Genelge, 2010, s.28).

Yukarıda içeriği açıklanmaya çalışılan Genelge BİT'in yaygın kullanımı, Bilgi Toplumuna geçiş, dijital geri kalmışlık, e-devlet, kültürel mirasın korunmasında BİT’in kullanılması gibi doğrudan kütüphaneleri 
ilgilendiren ve sonuçları kütüphanelere yansıyacak kavramlara dayanmaktadır. Belgede bu belirtilmemiş, bilgi toplumu-kütüphaneler ilişkisi doğrudan ilişkilendirilmemiş olsa da söz konusu kavramların hayata geçirilmesi ve kararların uygulanmasında kütüphaneler mutlaka rol almak durumundadır. Kütüphaneler, bu kapsamda, kullanıcılarına ücretsiz BİT eğitimi ve kullanım olanakları sağlayarak, internet kullanımını teşvik ederek, dijitalleştirme projeleri gerçekleştirerek, özellikle kişilerin e-devlet erişimlerine teknolojik destek ve kullanıcı eğitimi vererek, kültürel mirasın dijitalleştirilmesi çabaları ile önemli işlevler görmeye başlamıştır.

\subsection{Programlar}

\section{A.C. 2008-2013 Yıllarında Kütüphane ve Bilgi Alanının Gelişstirilmesine Yönelik Devlet Programı}

Bu belgede, kütüphanelerde mevcut teknik altyapının zayıf, kütüphane binalarının bakımsız durumda olması, personel yetersizliği, mesleki eğitimin zayıflığı, kütüphanecilik alanının gelişmesindeki engeller olarak değerlendirilmektedir. Bu saptamalar doğrudan bilgi toplumu-kütüphane ilişkisi bağlamında yapılmasa da kütüphanelerin geliştirilmesi açısından önemli görünmektedir. Söz konusu Devlet Programında kütüphane ve bilgi alanında yeni teknolojilerin uygulanması ve kullanılması, modern kütüphane ve bilgi altyapısının oluşturulması, kütüphane ve bilgi hizmetlerinin dünya standartlarına getirilmesi, entelektüel potansiyel, bilginin geliştirilmesi ve sürekli eğitim için koşullar oluşturulmasına yönelik vurgular yer almaktadır. Bu kapsamda yapıldığı belirtilen çalışmalar şunlardır:

- Bilgi toplumu oluşturma bağlamında ulusal bilgi politikasının oluşturulması;

- Azerbaycan'ın "Bilgi Toplumu" modelinin oluşturulması sürecine katks sağlama;

- Elektronik katalogların ve elektronik kütüphanelerin oluşturulması;

- Kütüphanelerin yeni bilgi teknolojileri ile donatılmasi;

- Mesleki eğitimin düzenlenmesi ve kütüphane personelinin geliştirilmesi (3072 sayılı Genelge, 2008-2013 Devlet Programi, s.4,6).

Görüldüğü üzere, Belgede diğer ilgili ifadelerin yanı sıra özellikle "Azerbaycan'ın 'Bilgi Toplumu' modelinin oluşturulması sürecine katkı sağlama" ifadesi bilgi toplumu-kütüphane ilişkisine yönelik doğrudan bir atıf sayılabilir. Söz konusu Program çerçevesinde modern kütüphanelerin oluşturulması, geliştirilmesi ve kütüphanelerin modern bilgi merkezleri olarak faaliyet gösterebilmesi için kütüphanebilgi ağının geliştirilmesi, böylece ulusal kültürel mirasın ve bilgi kaynaklarının gelecek nesillere aktarılması gereğine yönelik saptamalar da bu ilişki açısından önemlidir.

Kısaca, bu Programda kütüphanelerin geliştirilmesine yönelik olarak belirlenen engeller ve bu engellere ilişkin çözüm önerileri doğrudan olmasa da bilgi toplumu-kütüphane ilişkisinin kurulduğunu gösteren ifadeler olarak değerlendirilebilir.

\section{Okullara Bilgi ve İletişim Teknolojileri Sağlama Programı (2005-2007)}

$\mathrm{Bu}$ programın temel amacı, yeni bilgi teknolojilerini kullanarak Azerbaycan Cumhuriyeti'nde eğitim kalitesini iyileştirmeye hizmet edecek, her düzeydeki vatandaşlar için eşit firsatlar sunan bilgilendirilmiş bir toplum oluşturmaktır. Bu çerçevede programın içerdiği görevler şunlardır:

- Eğitimde bilgi ve iletişim teknolojilerinin kullanımına dayanan normatif ve metodolojik temelin geliştirilmesi;

- Azerbaycan dilinde eğitim sürecinde kullanılan modern e-öğrenme materyalleri, e-ders kitapları, $e$ kütüphaneler, dijital eğitim kaynaklarının geliştirilmesi, yaygınlaştırılması ve uygulanması;

- Bilgi teknolojileri temelinde modern eğitim yöntemlerinin geliştirilmesi, enformasyon sürecinin bilimsel-metodik olarak desteklenmesi;

- Öğrenciler için uzaktan eğitim hizmetinin oluşturulması;

- Öğrenciler için eğitim portalı ve web sitelerinin oluşturulması (A.C. Eğitim Bakanlığı, 2011, s.21,22).

$\mathrm{Bu}$ programda açıkça dile getirilmese de belirlenen görevlerin birçoğunun gerçekleştirilmesinde kütüphanelerin rol alması kaçınılmaz görünmektedir. Eğitimde bilgi teknolojilerinin kullanılması, eöğrenme materyalleri, e-ders kitapları, dijital eğitim kaynakları, enformasyon sürecinin desteklenmesi gibi ilgili ifadeler ile "e-kütüphanelerin yaygınlaştırılması" biçimindeki ifade bilgi toplumu-kütüphane 
ilişkisine yönelik bir yaklaşımın varlığına işaret sayılabilir. Eğitimde bilgi toplumu yaklaşımının kütüphaneleri ilgilendirecek bu maddeler bilgi toplumu-kütüphaneler ilişkisi duyarlılığ 1 açısından da önemlidir. Kısaca, bu program kütüphanelerin ulusal eğitim sürecindeki rolleri aracılığıyla da bilgi toplumu bağlamında işlev yükleneceklerine ilişkin stratejik ilkeler içermektedir.

\section{Bilgi Toplumu-Kütüphane İlişkisi Bağlamında Azerbaycan Ulusal Bilgi Toplumu Politikası Geliştirme Modeli Önerisi}

Bu araştırmada, Azerbaycan'ın ulusal bilgi toplumu politikası ile ilgili olduğu düşünülen resmi politika belgelerinin analizi ve değerlendirilmesi ile elde edilen bulgular temelinde ve bilgi toplumu-kütüphane ilişkisini güçlü biçimde içeren Azerbaycan Ulusal Bilgi Toplumu Politikası Geliştirme Modeli oluşturulmaya çalışılmışıır. Bu model önerisi çalışmasının temel amacı, Azerbaycan'da gündeme gelecek olası bir Ulusal Bilgi Toplumu Politikası geliştirme sürecinde kütüphane kurumuna ilişkin yaklaşımların ve stratejik ilkelerin doğru ve güçlü bir biçimde yer almasına dikkat çekmek ve katkıda bulunmaktır. Azerbaycan Ulusal Bilgi Toplumu Politikası Geliştirme Modeli adılla oluşturduğumuz bu model, hem bu konudaki literatürü hem de Azerbaycan'in en başta yönetimsel ve ayrıca toplumsal, ekonomik, kültürel vb. koşulları ve yapısı dikkate alınarak oluşturulmaya çalışılmıştır. Söz konusu model önerisi (Şekil 1) aşağıdadır.

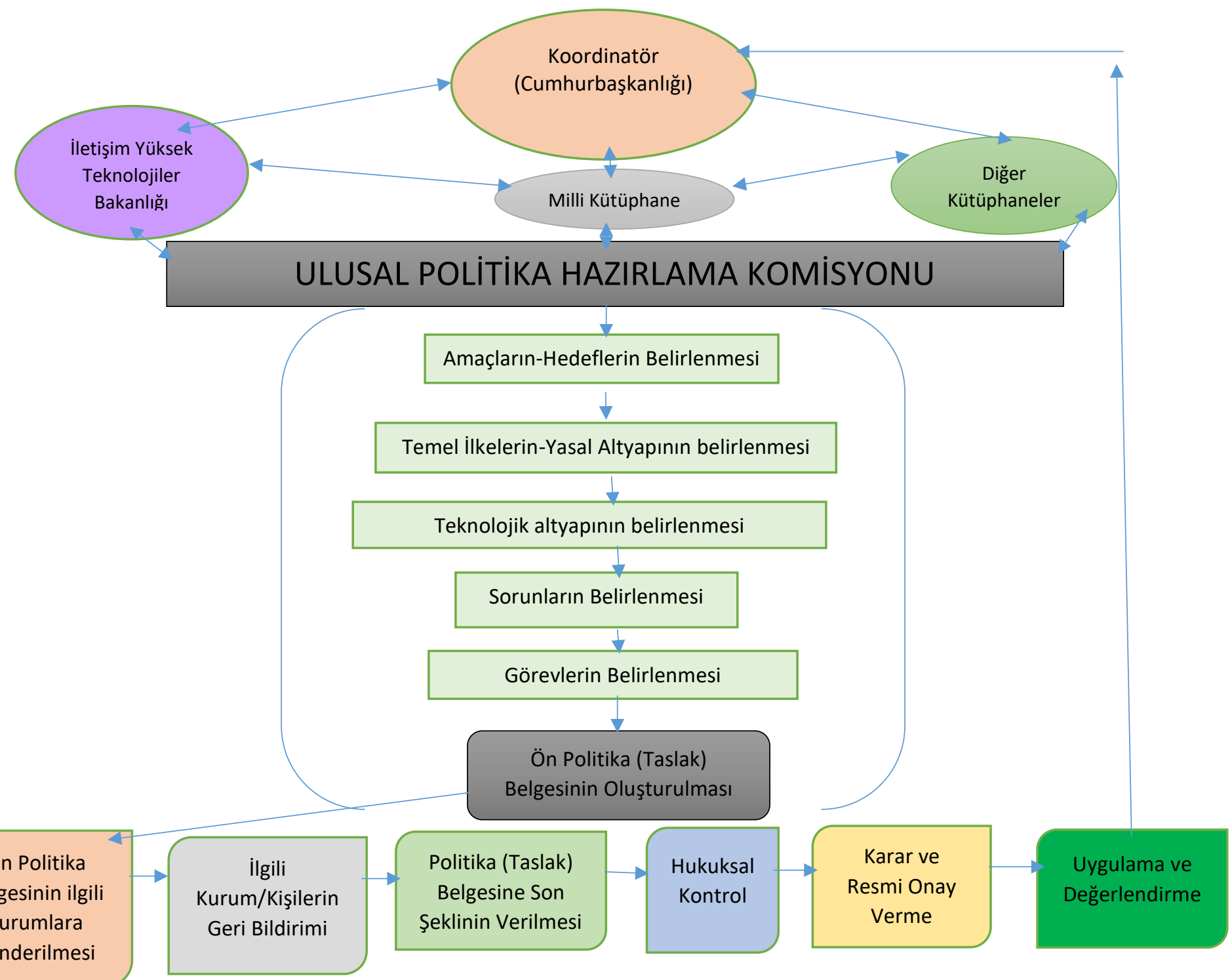

Şekil 1. Azerbaycan Ulusal Bilgi Toplumu Politikası Geliştirme Modeli

Öncelikle modelde yer alan başlıca kurumları ve işlevlerini açık biçimde yazmak yararlı olacaktır. Buna göre, 
- A.C. Cumhurbaşkanlı̆̆g, Azerbaycan'ın en yüksek siyasi makamı olduğu için bilgi politikası oluşturma ve uygulama sürecinin en önemli ve kritik kurumudur. A.C. Cumhurbaşkanliğ oluşturulan son politika belgesine resmi onayı verecek, uygulama sonuçlarını değerlendirecek ve tüm süreci yönetecek kurumdur.

- A.C. Illetişim ve Yüksek Teknolojiler Bakanlığı, ülkedeki iletişim ve bilgi teknolojilerinin geliştirilmesinden sorumlu devlet kurumudur. Ulusal Bilgi Toplumu Politikası oluşturma ve uygulama sürecinde özellikle teknolojik altyapı konusunda son derece işlevsel roller üstlenecektir.

- Milli Kütüphane, Azerbaycan'ın en önemli kütüphanesidir. Söz konusu sürecin kütüphaneler ayağını temsil edecektir.

- Diğer kütüphaneler, ülkede Milli Kütüphane dışındaki halk, okul, çocuk, üniversite kütüphaneleri gibi diğer kütüphaneleri ifade etmekte olup, sürecin ön politika oluşturma ve uygulama aşamalarında çok önemli roller üstleneceklerdir.

- Diğer ilgili kişi, kurum ve kuruluşlar, bu konuda görüş almak üzere ön politika belgesinin gönderileceği kişi ve kurumlardır. Bunlar, ekonomist, sosyolog, hukukçu, akademisyen, eğitimci, kültür uzmanı, planlamacı, kamu yöneticisi, politikacı vb. kişilerle, ekonomi, hukuk, eğitim, kültür ve diğer alanlardaki üniversite, bakanlık, kurum ve kuruluşlardır.

Önerdiğimiz Azerbaycan Ulusal Bilgi Toplumu Politikası Gelişstirme Modeli'nde temel yetkili, sorumlu ve koordinatör kurum Cumhurbaşkanlı̆̆ıdır. Azerbaycan'ın siyasal ve yönetimsel yapısı parlamenter cumhuriyet olmakla birlikte güçlü bir Cumhurbaşkanlığı yapısı söz konusudur. Dolayısıyla bu politikanın oluşturulma sürecini başlatma, yönetme, sürdürme ve uygulamaya geçirme iradesinin (yetki ve sorumluluğunun) doğrudan Cumhurbaşkanlığına ait olması hem yönetimsel yapı ile ilgilidir hem de ilgili politika oluşturma ve uygulama sürecini güçlendirecektir. Ulusal politikaları oluşturan ve uygulayan otoritenin o ülkede en yüksek düzeyde olması ideal bir durum olarak bilinir ve tercih edilir. $\mathrm{Bu}$, ilgili politikanın hem oluşturulma sürecini hem de uygulanma sürecini doğrudan ve olumlu biçimde etkiler. Cumhurbaşkanlığ bağlı İletişim Yüksek Teknolojiler Bakanlığı, Milli Kütüphane ve belirlenecek diğer kütüphaneler ile birlikte ve koordineli biçimde çalışacaktır.

Modelde Cumhurbaşkanlığına bağlı olarak çalışacak bir Ulusal Politika Hazırlama Komisyonu yer almaktadır. En üstte Cumhurbaşkanlığına, onun altında İletişim Yüksek Teknolojiler Bakanlığı, Milli Kütüphane ve belirlenecek diğer kütüphanelere bağlı olarak çalışacak ve sorumlu olarak çalışacak bu Komisyon politikaları oluşturma çalışmalarını başlatacak, değerlendirecek ve kendi üstünde yer alan makamlara iletecektir. Bu komisyon ilgili konudaki uzman, bürokrat ve uygulamacılardan oluşacaktır.

Ulusal Politika Hazırlama Komisyonu'nun başlıca görevi Bilgi Toplumu-kütüphaneler ilişkisini içeren bir ön politika belgesi (Taslak Politika Belgesi) olacaktır. Komisyon ön politika belgesini hazırlarken öncelikle bu politika ile ilgili amaçları, hedefleri, ilkeleri, yasal altyapıy1, teknolojik olanakları ve sorunları belirleyecek ve değerlendirecektir. Bu süreçte gereksinim duyduğu tüm bilgi ve belgeleri ilgili kurumlardan elde edecektir. Daha sonra bir taslak ön politika belgesi hazırlayacaktır.

Modele göre, Ulusal Politika Hazırlama Komisyonu'nun hazırladığı taslak politika belgesi değerlendirilmek, tartışılmak ve görüş alınmak üzere ülkede ilgili kişi, kurum ve kuruluşlara gönderilecektir. Bu kişi ve kurumların geri bildirimleri Komisyon tarafından değerlendirilecek ve taşlat politika belgesine son biçimi verilecektir. Hukuksal incelemesi de yaptırılacak ulusal politika resmi onay için Cumhurbaşkanlığı'na gönderilecektir. Cumhurbaşkanlığg son değerlendirmeyi ilgili bakanlık, Milli Kütüphane ve diğer kütüphanelerle birlikte yaparak resmileşen politikayı uygulamaya geçirecektir. Uygulama sonuçları belirli zaman aralıkları ile değerlendirilecek, aksamalar ve olumsuzluklar giderilecektir.

$\mathrm{Bu}$ modelde önerilen ulusal politikanın avantajları şunlar olacaktır:

1. Azerbaycan'da bilgi toplumu oluşturma konusunda hedefler, bu hedeflere ulaşmak için en uygun yol ve yöntemler ve kısaca somut bir yol haritası hazırlanmış olacaktır. 
2. Bu yol haritası ulusal strateji/politika anlamına gelecek ve buna dayalı olarak kısa, orta ve uzun vadeli planlar ve programlar yapılabilecek ve projeler geliştirilecektir.

3. Böyle bir ulusal politika Azerbaycan'ın bilgi toplumuna yol almasına k1lavuzluk edecek, bu süreci profesyonelce yönetmesini ve bilgi toplumuna kısa sürede ulaşmasını sağlayacaktır.

4. Bu politika sayesinde ülkede bu konu ile ilgili tüm kurum ve kuruluşların gelişmesi de söz konusu olacaktır.

5. Kütüphanelerle güçlü bağları kurulmuş bir bilgi toplumu politikası Azerbaycan'ın genel toplumsal gelişimini sağlayacak, onu çağdaş dünyanın bir parçası yapacaktır.

\section{Sonuç ve Öneriler}

$\mathrm{Bu}$ çalışmanın temel amacı, Azerbaycan Cumhuriyeti'nin bilgi toplumu politikasında kütüphane kurumuna yönelik yaklaşımı değerlendirerek, konuya ilişkin durumu ortaya koymak olarak belirlenmiştir.

Azerbaycan'ın bilgi toplumu politikası ile ilgili ulusal politika belgelerinde kütüphane kurumuna yaklaşım açısından bulgulara dayalı olarak yaptığımız değerlendirme ile ulaşılan genel sonuç, "ulusal bilgi toplumu politikasının kütüphane kurumunu belirli ölçüde dikkate aldığı" yönündedir. Bu dikkate alış bazı belgelerde dolaylı olarak, bazı belgelerde ise doğrudan ilişkilendirme biçimindedir.

Ayrıca, genel olarak söylemek gerekirse, Azerbaycan'ın bilgi toplumu yaklaşımında bilgi toplumukütüphane ilişkisi bazı politika belgelerinde güçlü, bazı politika belgelerinde ise zayıf bir biçimde ele alınmıştır.

Çalışmada bu genel sonuçlar bağlamında elde edilen diğer sonuçlar ise kısaca şöyle sıralanabilir:

- Azerbaycan'da bilgi toplumunun oluşturulmasında mevcut sorunları belirli ölçüde ortaya koyan A.C. Kütüphane ve Bilgi Alanının Geliştirilmesine Yönelik Devlet Programı (2008-2013) kütüphanelerin durumunun iyileştirilmesi ve işbirliği konusunda teşvik edici niteliktedir. Ancak bu politika belgesinin kütüphaneleri tam olarak bilgi toplumunun organik parçası olarak gördügünü söylemek mümkün değildir.

- Okullara Bilgi ve İletişim Teknolojileri Sağlama Programı (2005-2007) çerçevesinde okul kütüphaneleri eğitimde önemli yere sahip kurumlar olarak değerlendirilmekte ancak bilgi toplumunun "olmazsa olmaz" kurumları olarak değerlendirilmemektedir.

- Azerbaycan'da Kütüphanelerin Faaliyetlerinin Geliştirilmesi Hakkında Genelgeye (2007) göre, ulusal bilgi toplumu politikasının oluşturulmasında kütüphane ile işbirliğinin yapılmasının gereğine yapılan vurgu çok önemlidir ancak yeterince kapsayıcı ve güçlü görünmemektedir.

- Azerbaycan Dilinde Latin alfabesi ile Kitle Yayınların Gerçekleştirilmesine Yönelik Genelge (2004)'ye göre, Azerbaycan dilini, tarihini, kültürünü ve geleneklerini yansitan eserlerin Latin alfabesiyle yeniden yayımlanması ve okul kitaplarının Latin alfabesi ile yeniden basılması sonrası kütüphanelerin üstlenmesi gereken rol vurgulanmıştır.

- Enformasyon, Bilgilendirme ve Bilgi Güvenliği Hakkında Kanun'da bilgi kaynaklarının güvenliği kapsamında ele alınan kütüphaneler, arşivler, fonlar, veri bankaları bilgi merkezleri olarak değerlendirilmektedir.

- A.C. İletişim ve Bilgi Teknolojileri Geliştirme Devlet Programinin (Elektron Azerbaycan, 20102012) Onaylanması Hakkında Genelge gov.az ve e-devlet gibi uygulamalara yönelik yeniliklerin gerçekleştirilmesi ve toplumsal dijital geri kalmışlı̆ı azaltma konularında olumlu katkıları sağlamasına karşın kütüphane kurumuna yönelik doğrudan atıf yapılmamakta, sadece " maddi ve kültürel mirasın korunması ve geliştirilmesi için BİT kullanımını sağlamak" şeklinde bir ifade kullanılmaktadır. Kuşkusuz kütüphanelerin gelişimini ve teknoloji çağına hızlı uyumunu sağlamak için BİT'in yaygın kullanılması gerekmektedir. Ayrıca, BİT'in yaygın kullanımı da kütüphanelerin vatandaşlar bu bilgi-beceriyi ve teknolojik olanakları sunmasıyla ilgilidir. 
- A.C. Bilgi Toplumunun Gelişstirilmesine Yönelik Ulusal Stratejisi (2014-2020) Bi̇T teknolojilerinin geliştirilmesi, tarihsel, kültürel miras ve internet kaynaklarının (dijital arşivler) oluşturulması ve geliştirilmesi, kütüphane, arşiv ve müzelerde teknoloji uygulamalarının genişletilmesi, elektronik kütüphane ağının oluşturulması, kültürel mirasın korunması ve sayısallaştırma sürecinin hızlandırılması gibi önemli konuları kapsamaktadır. Fakat ulusal bilgi toplumu politikasının geliştirilmesinde kütüphanelerin rolü tam olarak açıklanmamakta ve diğer bilgi toplumu kurumları ile kütüphaneler arasında olması gereken güçlü işbirliği yaklaşımı görülmemektedir.

- Azerbaycan'in Geleceğe Bakış Kalkınma Konsepti (2020) kütüphane kurumuna yaklaşım konusunda özellikle eğitimle olan bağı çerçevesinde kütüphanelerin yenilenmesi, e-kütüphanelerin sayısının artırılması, uzaktan eğitimin geliştirilmesi ve özellikle yükseköğretim kurumlarında bu eğitimin desteklenmesi konusuna doğrudan atıfta bulunulması olumlu olarak değerlendirilmiştir.

Araştırmada elde edilen sonuçlara ve modele dayanarak ayrıca şu öneriler sunulabilir:

- Bilgi toplumu politikalarının oluşturulması ve uygulanmasında kütüphane kurumuyla mutlaka işbirliği içinde çalışılmalıdır.

- Ulusal bilgi politikasi/stratejisi belirlenirken alanla ilgili akademisyenlerin ve ilgili bölümden mezun olan uzman kütüphanecilerin fikirlerine başvurulmalıdır.

- Yurt dışında bilgi toplumu politikasının oluşturulması yöntem ve stratejileri öğrenilmeli ve gerekirse uzmanlar davet edilmelidir.

- Bilgi toplumuna yönelik çalışmalarda kütüphane-eğitim ilişkisinin yaygınlaşması nedeniyle ortak değerlendirmeler yapılmadır.

- Kütüphanelerin bilgi toplumu politikası oluşturulmasında ve uygulanması süreçlerinde amaçları, hedefleri, ilkeleri, rolleri ve stratejisi açı bir şekilde belirlenmelidir.

- Ulusal bilgi toplumu politikası oluşturma ve uygulama kapsamında mevcut sorunların çözümlenmesi için bilgi toplumu politikasına ilişkin temel ilke ve yasal altyapının oluşturulması ile ortak komisyonun görevlerinin belirlenmesi çok önemlidir.

Ulusal bilgi toplumu politikası oluşturmada ve uygulamaya geçirmede kütüphaneler olmazsa-olmaz kurumlardır. Onların bu süreçlerdeki vazgeçilemez rolleri iyi ve doğru biçimde değerlendirilmelidir. Kütüphanelerin bilgi toplumu oluşturma ve uygulama sürecine dâhil edilmesi ulusal bilgi toplumu politikasının gerçekleştirilmesine de ciddi bir destek verir. Bir toplumun bilgi toplumuna dönüşmesi ilgili kurumların işbirliğine dayanmaktadır. Dolayısıyla bilgi toplumu-kütüphane ilişkisi çerçevesinde kütüphanelerin önemi ve işlevleri kabul edilmeli ve onlara gerekli olanaklar sağlanmalıdır.

\section{Etik Standartlar ile Uyumluluk}

Çıkar Çatışması: Yazarlar herhangi bir çıkar çatışmasının olmadığını beyan eder.

Etik Kurul İzni: Bu çalışma için etik kurul iznine gerek yoktur.

Yazar Katkı Beyanı: Yazarlar makale için eşit oranda katkıda bulunduklarını beyan ederler.

Finansal Destek: Yoktur.

\section{Kaynakça}

2014-2020 Y1lları Azerbaycan Cumhuriyeti’nin Bilgi Toplumunun Geliştirilmesine Yönelik Ulusal Stratejisi. Erişim adresi: https://president.az/articles/11312

Azerbaycan 2020: Geleceğe Bakış Kalkınma Konsepti (2012, Kararname). Erişim adresi: https://president.az/files/future az.pdf 
“2010-2012 Azerbaycan Cumhuriyeti İletişim ve Bilgi Teknolojileri Geliştirme Devlet Programının (Elektron Azerbaycan) Onaylanması Hakkında (1056 sayılı Genelge). Erişim adresi: http://eqanun.gov.az/framework/19936

“2008-2013 yıllarında Azerbaycan Cumhuriyeti'nde Kütüphane ve Bilgi Alanının Geliştirilmesine Yönelik Devlet Programı (3072 sayılı Genelge). Erişim adresi: http://www.eqanun.az/alpidata/framework/data/15/c_f_15493.htm

460 sayılı Enformasyon, Bilgilendirme ve Bilgi Güvenliği Kanunu. Erişim adresi: http://eqanun.gov.az/framework/3525

Abbasov, C. (2005). Azerbaycan Cumhuriyeti'nin İktisadi ve Sosyal Coğrafyast. Bakü: AzTU Yay. Erişim adresi: http://elibrary.bsu.az/books aysel/N -144.pdf

ACDİK. Azerbaycan Cumhuriyeti Devlet İstatistik Kurumu. (2020). Demografik Göstergeler. Erişim adresi: https://www.stat.gov.az/news/index.php?id=4131 adresinden erişildi.

Ahmedov, İ. (2013). Eğitimin Bilgilendirilmesi Pedagojik Bilimin Yeni Bir Alanıdır. Azərbaycan Müallimi Erişim adresi: http://www.anl.az/down/meqale/az_muellimi/2013/mart/299822.htm

Aliguliyev, R. ve Mahmudov, R. (2016). Bilgi Toplumu Oluşumunun Çok Disiplin Bilimsel Sorunları. Informasiya Camiyyati Problemlari, 2, 3-18. Erişim adresi: https://jpis.az/uploads/article/az/MULTIDISCIPLINARY_SCIENTIFIC_THEORETICAL_PROB LEMS_OF_FORMATION_OF_INFORMATION_SOCIETY.pdf

Azerbaycan Cumhuriyeti Anayasası (1995). Erişim adresi: https://static2.president.az/media/W1siZiIsIjIwMTgvMDMvMDkvNXdmMDZvdmx2Y19Lb25zdG 10dXNpeWFfQVpFLnBkZiJdXQ?sha=d654e4f6cd152b25

Azerbaycan Cumhuriyeti Eğitim Bakanlığı. (2011). Kütüphane İşi ile ilgili Normatif Belgeler Toplusu (genel kütüphaneler iç̧in). Bakü: Nergiz Yay. Erişim adresi: https://www.repk.az/uploads/files/normativ aktar.pdf

Ergun, A. (2010). Azerbaycan'da Bir Ulusal Kimlik Meselesi Olarak Alfabe Değişikliği. bilig, Türk Dünyası Sosyal Bilimler Dergisi, 54, 139-160.

Gasımova, R. ve Elekberova, İ. (2006). Bilgi Toplumu ve Eğitim. Azərbaycan Müallimi. Erişim adresi: http://anl.az/down/medediyyet_2006/informasiya_cemiyyeti_ve_tehsil_azerbaycan_muellimi_2006 _15_iyun_s_5.htm

Hacızade, M. (2015). Azerbaycan'da Bilgi Toplumunun Oluşumu İlkeleri ve Kalkınma Süreçleri. Informasiya Camiyyati Problemlari, 2, 71-81. Erişim adresi: https://jpis.az/uploads/article/az/FACTORS OF INFORMATION SOCIETY FORMATION AN D_DEVELOPMENT_TRENDS_IN_AZERBAIJAN_.pdf.

Kaptan, S. (1995). Bilimsel Araştırma ve İstatistik Teknikleri. Ankara: Gazi Üniversitesi.

Koçak, A. ve Arun, Ö. (2006). İçerik Analizi Çalışmalarında Örneklem Sorunu. Selçuk İletişim, 4 (3), 21-28.

Montviloff, V. (1990). National Information Policies. Paris: UNESCO.

Nuriyeva, İ. (2015). Azerbaycan Tarihi: En Eski Çağlardan XXI. Yüzyılın Başına Kadar (üniversiteler için ders kitabı). Bakü: Mütercim. Erişim adresi: http://anl.az/el/Kitab/2015/Azf-282700.pdf

Süleymanov, T., Gasımova, T., Paşayeva, M. ve Cebrayılova, A. (2015). "Bilgi Toplumunda Bilgi Kültürünün Oluşum Sorunları”. Bilgi Güvenliğinin Çok Disiplinli Sorunları Üzerine II Cumhuriyet Bilimsel-Pratik Konferansl. Bakü, Azerbaycan 17 Mayıs. 95-98. Erişim adresi: https://ict.az/uploads/konfrans/2_konfrans/24.pdf

Tonta, Y. (1999). “Bilgi Toplumu ve Bilgi Teknolojisi. Türk Kütüphaneciliği, 13 (4), 363-375. 
Tonta, Y. ve Küçük, M. E. (2005). Sanayi Toplumundan Bilgi Toplumuna Geçiş Sürecinde Temel Dinamikler. Türk Kütüphaneciliği, 19, (4) 449-464.

Yılmaz, B. (1997). "Ulusal Bilgi Politikası: Kuramsal Bir Yaklaşım”. 33.Kütüphane Haftası Bildirileri. Ankara, Türkiye 31 Mart-6 Nisan. 22-30. Türk Kütüphaneciler Derneği.

Yılmaz, B. (2010). “Türkiye'nin Bilgi Toplumu Politikasında Kütüphane Kurumuna Yaklaşım”. Bilgi Dünyast, 11 (2), 263-289. 